\title{
Augmented Reality Marker Based Tracking Visualisasi Drawing 2D ke dalam Bentuk 3D dengan Metode FAST Corner Detection
}

\author{
Nanang Wahyudi, Teknologi Informasi ISTTS, Reddy Alexandro Harianto., S.Kom., M.Kom., \\ Informatika ISTTS, Endang Setyati, Dr., Ir., Hj.,, M.T., Teknologi Informasi ISTTS
}

\begin{abstract}
Abstrak- Augmented Reality (AR) memungkinkan pengguna dapat melihat objek virtual pada lingkungan nyata. Berbeda dengan Virtual Reality (VR) yang membawa pengguna masuk pada lingkungan virtual sepenuhnya tanpa melihat dunia nyata. Teknologi AR menggunakan marker sebagai target untuk memunculkan objek virtual. Penelitian ini menggunakan Drawing 2D sebagai Marker Based Tracking dalam mendeteksi target untuk memunculkan objek 3D virtual. Gambar 2D atau Drawing 2D merupakan alat untuk menyampaikan maksud dan informasi dari drafter kepada teknisi. Siswa lulusan Sekolah Menengah Kejuruan (SMK) harus mampu memahami Drawing 2D dan memvisualisasikan kedalam bentuk 3D. Kemampuan spasial dalam memvisualisasi ini harus dimiliki karena menyangkut masa depan setiap siswa. Penyampaian materi proyeksi Drawing 2D memerlukan teknis khusus agar mampu di pahami oleh siswa. Aplikasi AR ini menggunakan metode Features from Accelerated Segment Test Corner Detection (FCD) dalam proses tracking yang memiliki tingkat komputasi deteksi marker yang tinggi untuk memunculkan objek virtual 3D. Uji coba penelitian menggunakan 50 marker. Kriteria uji coba tracking dengan posisi marker antara lain : tegak lurus, miring $30^{\circ}, 45^{\circ}, 60^{\circ}$ dan $75^{\circ}$ serta dengan jarak deteksi $20 \mathrm{~cm}, 30 \mathrm{~cm}$, $40 \mathrm{~cm}, 50 \mathrm{~cm}$, dan $60 \mathrm{~cm}$ terhadap kamera. Dari hasil uji coba untuk mendeteksi 50 marker dapat disimpulkan bahwa marker dapat terdeteksi dengan posisi tegak lurus terhadap kamera maksimum jarak $50 \mathrm{~cm}$, posisi marker miring $30^{\circ}$ terdeteksi maksimum pada jarak $40 \mathrm{~cm}$, dan posisi marker miring $45^{\circ}$ terdeteksi maksimum pada jarak $30 \mathrm{~cm}$. Untuk kemiringan marker $60^{\circ}$ dan $75^{\circ}$ rata-rata perangkat sudah tidak dapat mendeteksi marker. Proses deteksi marker dapat dipengaruhi oleh spesifikasi perangkat yang digunakan dalam ujicoba, pencahayaan, ukuran marker serta ketebalan garis yang digunakan.
\end{abstract}

Kata Kunci-Augmented Reality, FAST Corner Detection, Gambar Teknik, Kemampuan Spasial

\section{PENDAHULUAN}

A ugmented Reality merupakan teknologi yang dapat menggabungkan objek virtual dengan lingkungan nyata secara real time. Azuma telah mengembangkan penelitian terkait teknologi augmented reality yang memungkinkan

Nanang Wahyudi, Departemen Teknologi Informasi, Institut Sains dan Teknologi Terpadu Surabaya, Surabaya, Jawa Timur, Indonesia (e-mail: nanang wahyudie@yahoo.co.id )

Reddy Alexandro Harianto, S.Kom., M.Kom., Departemen Informatika, Institut Sains dan Teknologi Terpadu Surabaya, Surabaya, Jawa Timur, Indonesia (e-mail: reddy@stts.edu )

Endang Setyati, Dr., Ir., Hj.,, M.T., Departemen Teknologi Informasi, Institut Sains dan Teknologi Terpadu Surabaya, Surabaya, Jawa Timur, Indonesia (e-mail: endang@stts.edu ) pengguna untuk melihat dunia nyata bersama dengan objek virtual [1]. Augmented Reality (AR) berbeda dengan Virtual Reality (VR) ataupun Mixed Reality (MR). AR dan MR memungkinkan pengguna dapat melihat dan berinteraksi dengan objek virtual 3D pada lingkungan nyata. Sedangkan VR membawa pengguna pada dunia virtual tanpa melihat atau berinteraksi dengan dunia nyata.

Teknologi AR memerlukan target yang digunakan sebagai kunci dalam memunculkan objek 3D virtual yang disebut dengan marker [2]. Marker dapat menggunakan barcode bergaris, QR Code atau gambar bebas [3]. Marker terbagi menjadi 2 jenis yaitu : marker based tracking dan markerless.

Dengan perkembangan teknologi yang semakin cepat kini teknologi AR dapat digunakan secara mobile dan di manfaatkan pada berbagai bidang seperti bidang pendidikan, bidang kesehatan dan bidang militer [4]. Pada bidang pendidikan khususnya untuk pembelajaran proyeksi menggambar 2D memerlukan kemampuan spasial dalam memvisualisasi ke dalam bentuk objek 3D atau sebaliknya. Dalam memberikan pemahaman terhadap materi menggambar 2D dan 3D memerlukan teknik khusus serta alat dalam menyampaikan materi yang nantinya mampu di fahami oleh siswa. Pembelajaran dengan waktu yang relatif singkat juga menjadi salah satu faktor kendala penyampaian pemahaman siswa dalam memahami gambar 2D.

Gambar 2D atau disebut juga dengan Drawing 2D merupakan alat bantu dalam menyampaikan informasi untuk membuat benda kerja atau pekerjaan teknik [5]. Seorang siswa lulusan Sekolah Menengah Kejuruan (SMK) terutama pada jurusan teknik pemesian dan teknik otomotif harus mampu memahami drawing 2D dan memvisualisasikan kedalam bentuk 3D. Kemampuan spasial dalam memvisualisasi ini merupakan skill atau keahlian yang harus dimiliki oleh setiap siswa karena menyangkut masa depan siswa di kemudian hari dalam bekerja.

Penelitian pengembangan teknologi AR dalam menggambar 2D dan penelitian terkait pengembangan

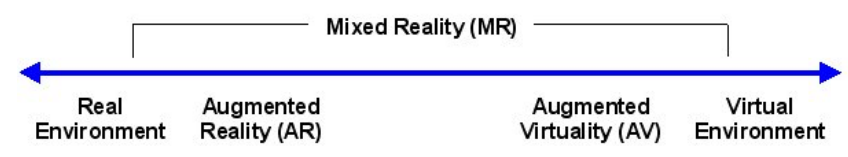

Gambar 1. Satuan Reality-Virtuality dengan Milgram 
kemampuan spasial yang telah dilakukan oleh beberapa peniliti. Jorge Martin G. membuktikan bahwa kemampuan spasial dalam pemahaman gambar teknik dapat ditingkatkan dengan bantuan teknologi AR [6]. Heen Chen mengembangkan teknologi AR dalam visualisasi 3 jenis proyeksi gambar teknik 2D ke dalam objek virtual 3D [7]. Untuk proses deteksi marker (tracking) metode FAST (Features from Accelerated Segment Test) Corner Detection memiliki tingkat komputasi yang tinggi jika dibandingkan dengan metode Harris Corner Detection dan Edge Based Corner Detection [8].

Berdasarkan permasalahan tersebut maka penelitian ini memberikan alternatif teknologi Augmented Reality untuk memvisualisasikan drawing 2D kedalam bentuk objek 3D virtual. Proses deteksi marker sebagai target dalam memunculkan objek 3D menggunakan metode FAST (Features from Accelerated Segment Test) Corner Detection (FCD).

\section{STUDI LITERATUR}

\section{A. Augmented Reality}

Augmented Reality (AR) adalah penggabungan antara objek virtual dengan lingkungan nyata. AR menurut Paul Milgram merupakan penggabungan dunia nyata dan virtual, bersifat interaktif secara real time dan berbentuk 3D [9].

Augmented Reality memiliki hubungan yang erat dengan Virtual Reality dan Mixed Reality dimana sama-sama menambahkan objek virtual secara nyata. Namun untuk memahami hubungan tersebut dapat dilihat pada Gambar 1.

Augmented Reality (AR) didominasi dengan penambahan objek virtual di dunia nyata dengan informasi yang dihasilkan oleh komputer. AR dapat memberikan informasi tambahan berupa visual tambahan yang ditambahkan di dunia nyata dengan 6 derajat kebebasan (6 Degree Of Freedom (6DOF)).

Virtual Reality (VR) mengacu pada sistem yang sebagian besar berupa objek dan lingkungannya buatan. VR membawa seseorang ke dalam dunia komputer atau virtual tanpa bisa melihat dunia nyata dengan 3 derajat kebebasan (3 Degree Of Freedom (3DOF)).

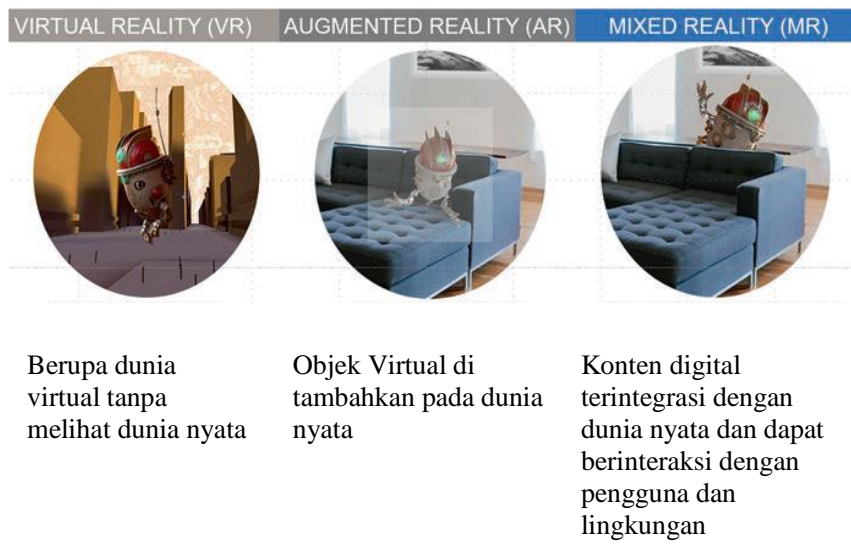

Gambar 2. Perbandingan Augmented Reality, Virtual Reality, dan Mixed Reality

Mixed Reality (MR) termasuk dalam dunia simulasi yang mengacu pada kombinasi atau penggabungan lingkungan virtual bersama dengan lingkungan nyata, dimana keduanya dapat hidup berdampingan. Mixed Reality juga disebut dengan "Hybrid Reality". Perbedaan AR, VR dan MR dapat dilihat pada Gambar 2.

Saat ini AR dan VR dapat dimanfaatkan untuk pelatihan, pendidikan dan hiburan. Dalam militer AR dapat digunakan sebagai alat untuk latihan berperang atau mekanik pesawat terbang. Di dunia kesehatan dan pendidikan AR dapat digunakan sebagai alat bantu dalam proses pembelajaran virtual. Hasil review dari beberapa riset terkait AR dalam dunia pendidikan menyimpulkan bahwa dengan perantara Augmented Reality mampu memberikan manfaat dan pengalaman belajar yang efektif dan dampak yang psositif bagi siswa. Hasilnya telah ditunjukkan dalam bentuk motivasi, kinerja pembelajaran, dan peluang baru untuk menciptakan pengalaman belajar yang interaktif.

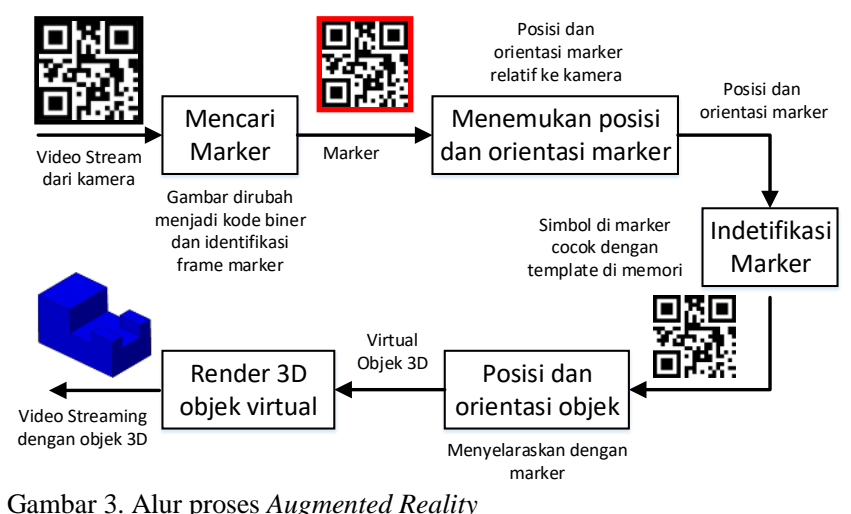

Pada Gambar 3 merupakan alur proses pada AR. Proses dimulai dari pengambilan gambar marker dengan kamera. Kemudian masuk ke dalam proses pencarian dan orientasi marker, indentifikasi marker, perhitungan posisi dan orientasi marker terhadap objek dan render objek. Proses render menggabungkan gambar asli dan komponen virtual menggunakan perhitungan pose dan orientasi marker. Hasil keluaran pelacakan marker ditampilkan pada layar komputer atau smartphone.

\section{B. Marker}

Marker merupakan sebuah penanda khusus yang memiliki pola tertentu yang akan dikenali oleh kamera, sehingga saat kamera mendeteksi marker maka objek 3D dapat ditampilkan. Marker Augmented Reality dapat dikategorikan menjadi dua yaitu deteksi menggunakan (Marker Based Tracking) dan tanpa marker (markerless). Marker based tracking komputer akan mengenali posisi dan orientasi marker dan menciptakan dunia virtual 3D [2][10]. Contoh marker yang digunakan pada penelitian ini seperti pada Gambar 4.

Marker atau bisa disebut dengan Image target memiliki kriteria untuk dapat dilacak oleh sistem AR yang meliputi :

a. Fitur gambarnya kaya (polanya rumit), misalnya gambar pemandangan, gambar sekumpulan orang, kolase dan lain-lain.

b. Kontrasnya bagus, gelab dan terangnya jelas.

c. Tidak ada pengulangan pola, misal lapangan rumput, kotak-kotak. 
d. Grafik warnanya 8 atau 24 bit format PNG atau JPG, ukurannya kurang dari 2MB, JPGs haruslah RGB atau grayscale (bukan CMYK).

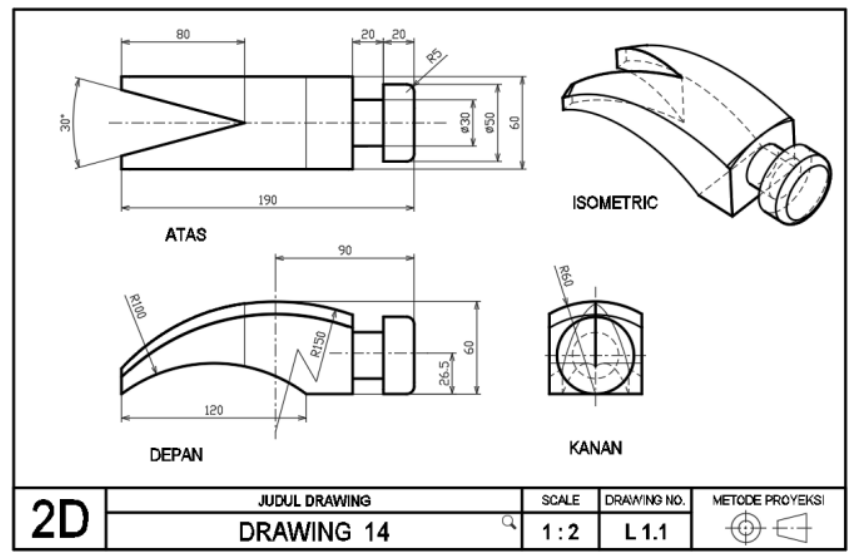

Gambar 4. Contoh marker drawing 2D

\section{Gambar Kerja / Drawing}

Gambar kerja atau drawing merupakan sebuah alat dalam memberikan informasi dari drafter atau seorang desainer kepada teknisi atau pembuat benda kerja [5].

Drawing 2D pada umumnya memiliki 2 jenis proyeksi gambar yaitu proyeksi sistem Amerika (Third Angle Projection) dan proyeksi sistem Eropa (First Angle Projection). Pada penelitian ini menggunakan drawing 2D dengan sistem amerika seperti pada Gambar 5.
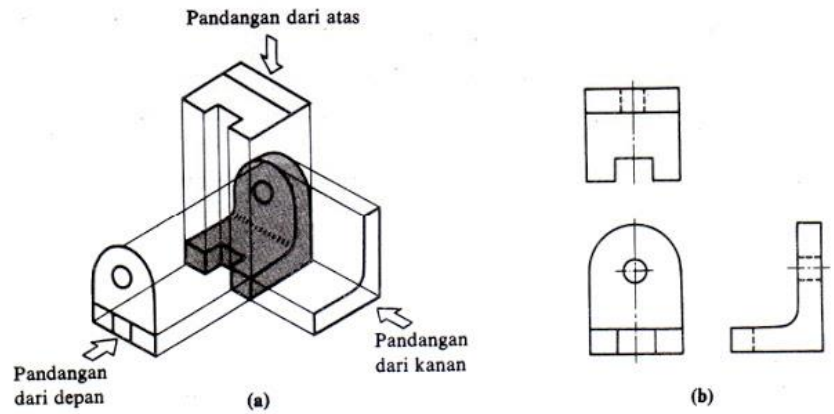

(b)

Gambar 5. Bentuk Proyeksi Pandangan Amerika

\section{FAST (Features from Accelerated Segment Test) Corner Detection (FCD)}

Algoritma FAST (Features from Accelerated Segment Test) Corner Detection (FCD) merupakan penentuan corner point atau deteksi sudut untuk mendeteksi sudut-sudut dari suatu objek yang dikembangkan oleh Edward Rosten, Reid Porter, dan Tom Drummond [11]. Algoritma FCD ini dibuat dengan tujuan mempercepat waktu komputasi secara realtime dengan konsekuensi menurunkan tingkat akurasi pendeteksian sudut [12].

Pada algoritma FCD proses penentuan corner point adalah dengan cara merubah gambar menjadi warna hitam dan putih. Algoritma ini menentukan corner point dengan sebuah titik yakni $\mathrm{p}$ dari input gambar yang memeriksa keliling 16 pixel dari titik $p$.

Metode FAST Corner Detection ini menggunakan jenis high-speed test FAST Corner Detection yang digunakan untuk mengecualikan jumlah besar dari non-corners (bukan sudut), dimana penerapan algoritma dengan mengambil
4 titik dari 16 pixel kemudian membandingkan intensitas keempat pixel dengan pixel titik $p$ (titik pusat). Jika nilai intensitas di titik $p$ bernilai lebih besar atau lebih kecil daripada intensitas sedikitnya tiga titik disekitarnya ditambah dengan intensitas batas ambang (threshold), maka didapatkan titik $p$ merupakan titik sudut (corner). Setelah itu titik $p$ akan digeser ke posisi $x_{p+1}, y_{p}$ dan melakukan perbandingan intensitas sampai semua titik pada citra. Tahapan proses dari algoritma FCD sebagai berikut :

1. Tentukan sebuah titik $p$ pada citra dengan posisi awal $(\mathrm{x}, \mathrm{y})$ dan nilai threshold seperti pada Gambar 6

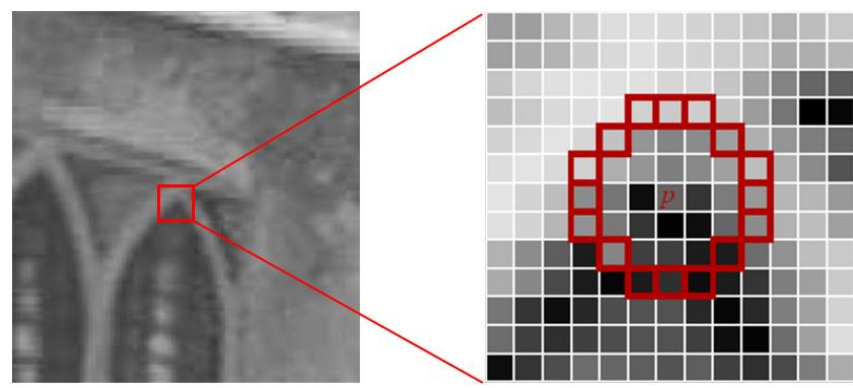

Gambar 6. Menentukan titik awal (titik P)

2. Tentukan 16 titik pixel dengan radius 3 pixel dari titik $p$ seperti pada Gambar 7.
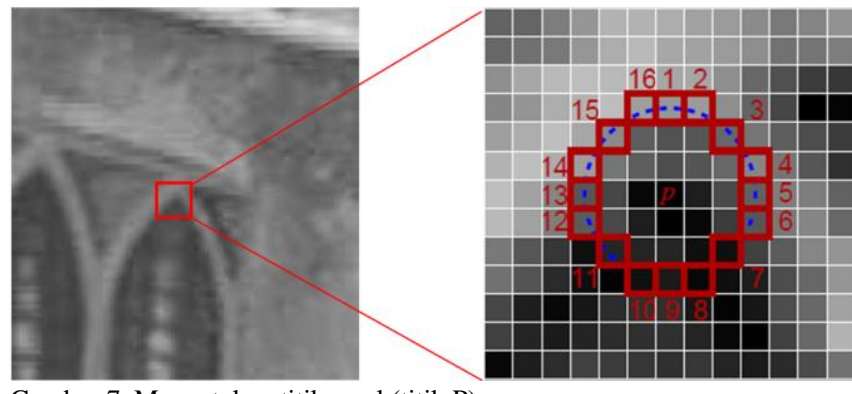

Gambar 7. Menentukan titik awal (titik P)

3. Tentukan lokasi 4 titik dari 16 pixel. Titik pertama $(n=1)$ koordinat $\left(x_{p}, y_{p+3}\right)$, titik kedua $(\mathrm{n}=2)$ koordinat $\left(x_{p+3}, y_{p}\right)$, titik ketiga $(\mathrm{n}=3)$ koordinat $\left(x_{p}, y_{p-3}\right)$, titik keempat $(\mathrm{n}=2)$ koordinat $\left(x_{p-3}, y_{p}\right)$ seperti pada Gambar 8.

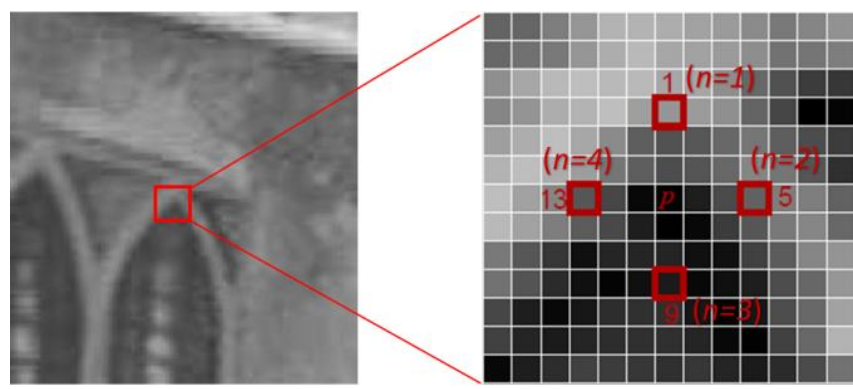

Gambar 8 . Titik p pada koordinat $n=1, n=2, n=3, n=4$

4. Bandingkan intensitas titik pusat $p$ dengan keempat titik disekitar. Titik pusat $p$ merupakan titik sudut atau corner seperti pada Gambar 9 apabila terdapat paling sedikit 3 titik yang memenuhi 3 kategori yang ditetapkan dalam algoritma FCD yaitu : 


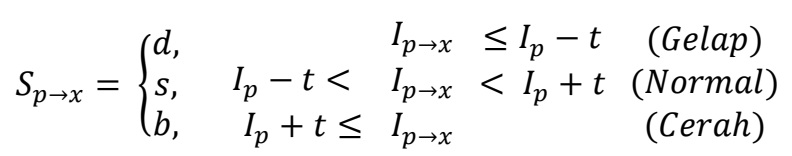

Keterangan :

$S_{p \rightarrow x}:$ Intensitas titik pusat (titik p)

$I_{p \rightarrow x} \quad:$ Intensitas pixel x (titik intensitas tetangga ke-n)

t : threshold

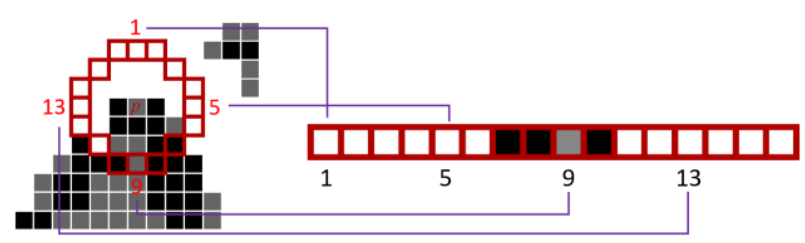

Gambar 9. Perbandingan intensitas pada 16 pixel dari titik $\mathrm{p}$

5. Ulangi proses sampai seluruh titik pada citra sudah dibandingkan intensitasnya.

Penerapan algoritma FCD dapat digambarkan pada diagram alir Gambar 10.

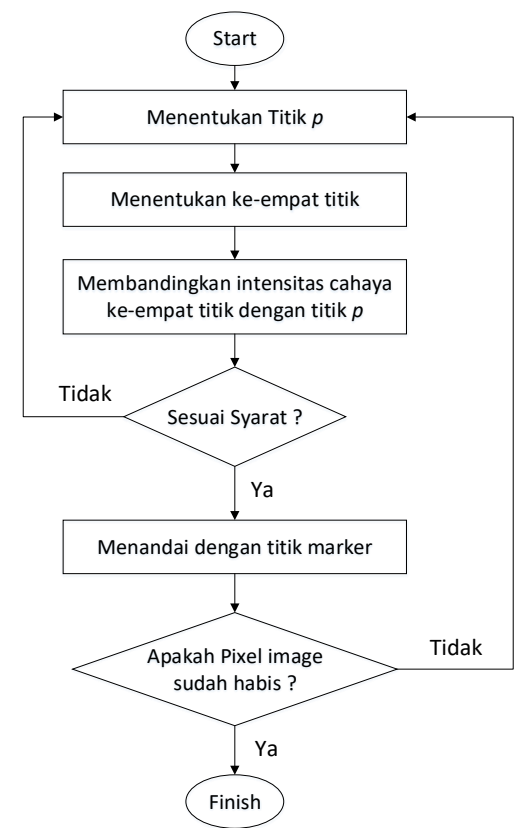

Gambar 10. Diagram alir algoritma FAST Corner Detection (FCD)

\section{E. Penelitian Terdahulu}

1. Penelitian AR menggunakan Marker based Tracking

1.1. AR-Dehaes

Jorge Martin G. membuat aplikasi pembelajaran gambar teknik sederhana bernama buku AR-Dehaes [13]. Metode AR menggunakan marker based tracking seperti pada Gambar 11. Metode sistem dapat dilihat pada blok diagram Gambar 12 dan deteksi marker (tracking) menggunakan 4 tahapan sebagai berikut :

1. Camera calibration

2. Marker detection

3. Calculation of marker position and orientation (pose estimation)

4. Augmentation of virtual object

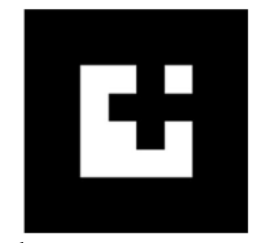

Gambar 11. Marker AR-Dehaes

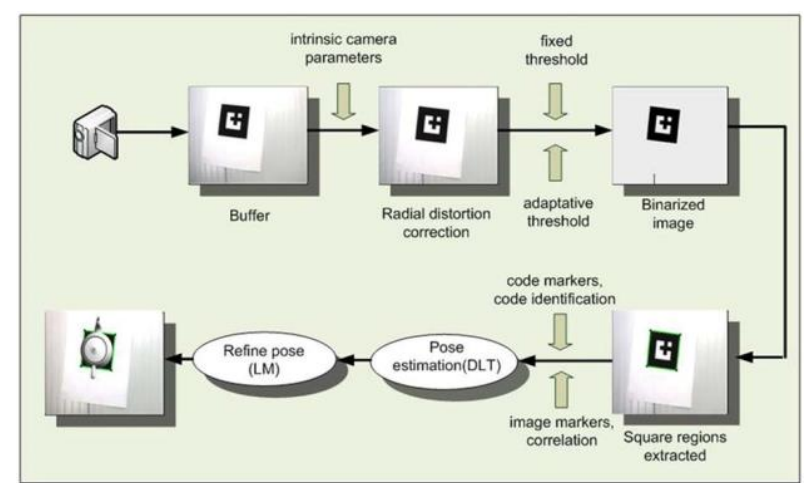

Gambar 12. Blok Diagram AR-Dehaes

\subsection{AR in Engineering Graphics Education}

Heen Chen mengembangkan teknologi AR dalam pembelajaran gambar teknik proyeksi 2D untuk divisualisasikan ke dalam objek virtual 3D [7]. Metode yang digunakan berupa proyeksi gambar teknik 2D yang diberikan marker sebagai acuan memunculkan objek 3D. Contoh gambar 2D seperti pada Gambar 13.

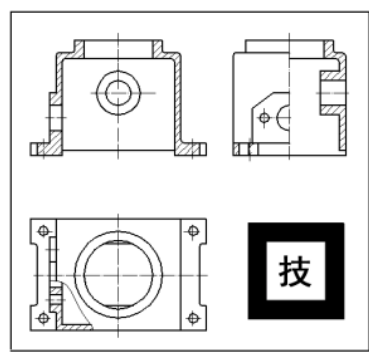

(a)

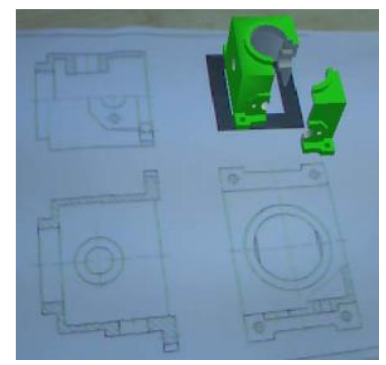

(b)
Gambar 13. (a). Gambar 2D beserta marker, (b) Visualisasi objek 3D virtual

2. Penelitian perbandingan tracking algoritma FCD

2.1. Perbandingan Tracking algoritma Harris Corner Detection, Edge Based Corner Detection dan Fast Corner Detection dalam Deteksi Senyum Pada wajah Manusia

Eduard Royce Siswanto melakukan perbandingan metode algoritma dalam deteksi senyum pada manusia [8]. Hasil dari penelitian menyatakan bahwa metode Fast Corner Detection memiliki tingkat komputasi tertinggi atau waktu yang pendek dalam mendeteksi citra dibandingkan dengan metode Harris dan Edge Based Detection. Hasil penelitian dapat dilihat pada Tabel 1 .

Tabel 1

Akurasi dan Waktu Komputasi Sistem Pendeteksi Senyum

\begin{tabular}{lcc}
\hline \multicolumn{1}{c}{ Metode } & $\begin{array}{c}\text { Akurasi } \\
(\%)\end{array}$ & $\begin{array}{c}\text { Waktu Komputasi } \\
\text { (mili detik) }\end{array}$ \\
\hline Harris Corner Detection & 29 & 70.6 \\
Edge Based Corner Detection & 42 & 50.9 \\
FAST Corner Detection & 59.5 & 13.1 \\
\hline \hline
\end{tabular}


2.2. Perbandingan Kinerja Algoritma Untuk Mendeteksi Objek Dua Dimensi Pada Augmented Reality

Rujianto Eko Saputro melakukan perbandingan metode FAST dan ORB dalam mendeteksi objek 2D [14]. Contoh objek 2D yang diuji pada Gambar 14. Hasil dari penelitian dapat dilihat pada Tabel 2. Hasil penelitian didapatkan bahwa metode FAST memiliki performa paling baik dibandingkan dengan algoritma ORB, pengujian algoritma FAST mampu menampilkan interest point antara 0 sampai dengan 2 milli seconds, sedangkan algoritma ORB mencapai 0 sampai dengan 15 milli seconds.

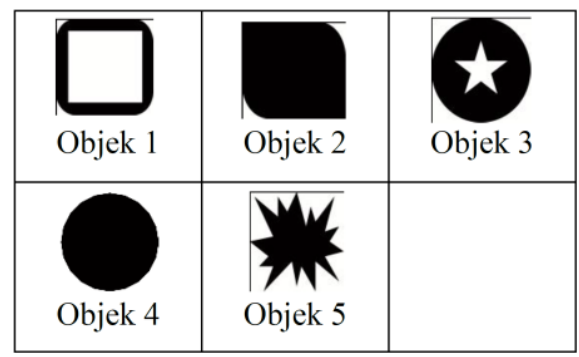

Gambar 14. Objek 2 dimensi yang diuji

Tabel 2

Kecepatan deteksi metode FAST dan ORB

\begin{tabular}{ccc}
\multicolumn{3}{c}{ Kecepatan deteksi metode FAST dan ORB } \\
\cline { 2 - 3 } Objek & Kecepatan Deteksi ( ms ) \\
\cline { 2 - 3 } Objek 1 & $0-1$ & ORB \\
Objek 2 & 0 & $0-13$ \\
Objek 3 & $0-1$ & $0-11$ \\
Objek 4 & $0-1$ & $1-15$ \\
Objek 5 & $0-1$ & $1-11$ \\
\hline \hline
\end{tabular}

\section{METODOLOGI PENELITIAN}

Proses pembuatan aplikasi dimulai dari pembuatan gambar 2D yang sekaligus digunakan sebagai marker. Kemudian membuat objek virtual 3D dan pembuatan aplikasi. Rancangan blok diagram proses pada Gambar 15 .

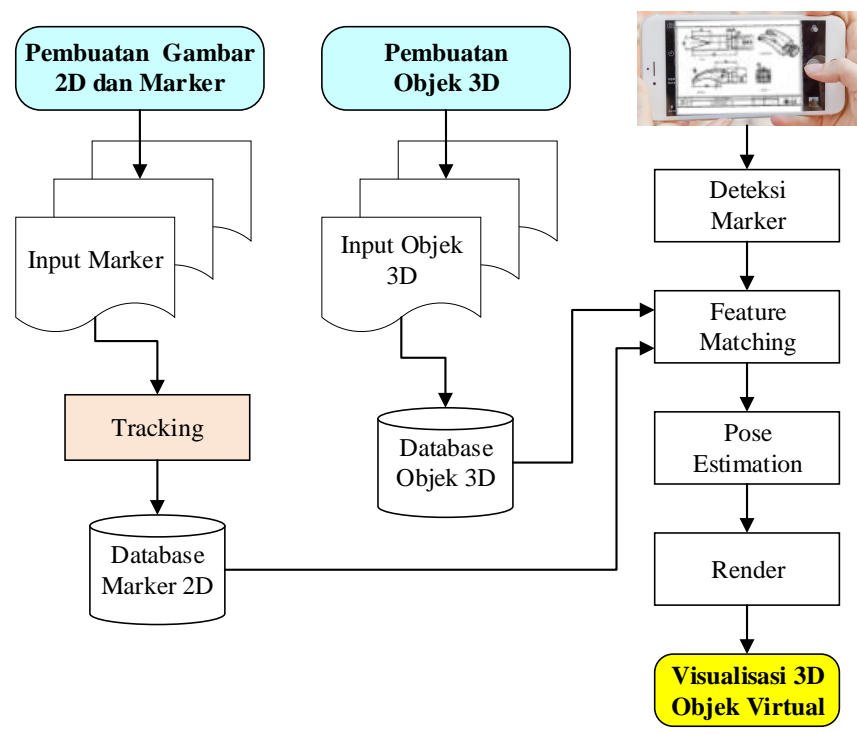

Gambar 15. Blok Diagram Rancangan Aplikasi AR

\section{A. Drawing 2D, Marker dan Objek 3D}

Input dari aplikasi menggunakan Drawing 2D yang sekaligus sebagai marker dibuat menggunakan autocad. Sedangkan untuk objek 3D virtual dibuat menggunakan aplikasi blender. Contoh drawing 2D dan objek 3D dapat dilihat pada gambar Gambar 16 dan Gambar 17.

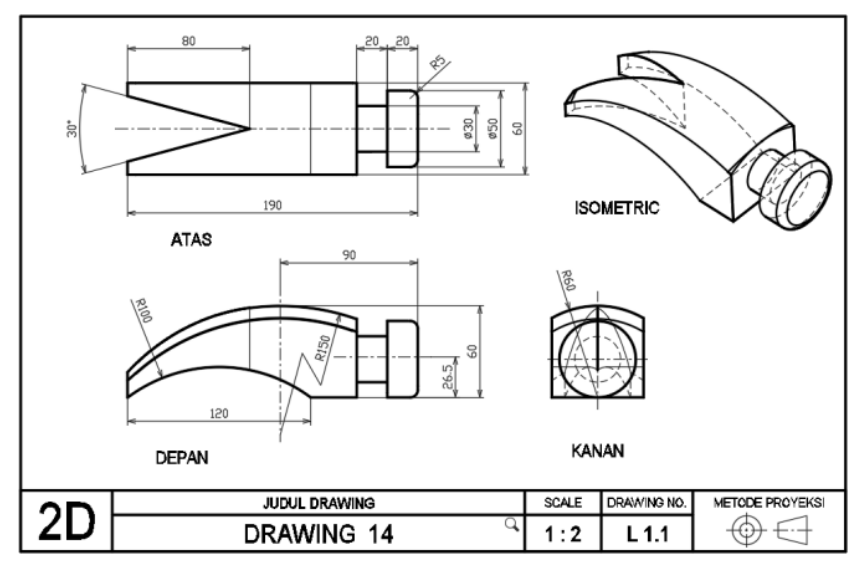

Gambar 16. Contoh Drawing 2D dan Marker

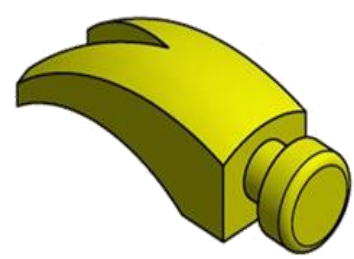

Gambar 17. Gambar 3D objek virtual

\section{B. Proses Tracking}

Aplikasi harus mengenali target atau marker untuk memunculkan objek 3D. Proses mengenali marker disebut dengan proses tracking. Tahapan dari proses tracking seperti pada Gambar 18.

\begin{tabular}{|c|c|c|c|c|}
\hline $\begin{array}{l}\text { Input } \\
\text { Marker }\end{array}$ & $\begin{array}{l}\text { Resize } \\
\text { Image }\end{array}$ & $\begin{array}{c}\text { Convert } \\
\text { Grayscale }\end{array}$ & $\begin{array}{l}\text { Binerisasi } \\
\text { (threshold) }\end{array}$ & $\begin{array}{c}\text { Deteksi } \\
\text { Poin Marker }\end{array}$ \\
\hline
\end{tabular}

Gambar 18. Tahapan proses tracking marker

a. Input Marker

Mempersiapkan marker sebagai target untuk memunculkan objek 3D

b. Resize Image

Proses ini bertujuan untuk menyamakan ukuran gambar dan memperkecil jumlah pixel sehingga proses perhitungan untuk mendeteksi marker semakin cepat.

c. Convert Grayscale

Proses ini merubah gambar menjadi grayscale atau hitam putih dengan nilai intensitas 0 sampai 255. Tujuan dari proses ini adalah untuk memudahkan sistem agar dapat mengenali pola pada gambar yang diterima.

d. Binerisasi (threshold)

Proses binerisasi dilakukan dengan cara mengkonversi citra grayscale ke dalam biner dengan nilai threshold default adalah 128, jika pixel yang nilai intensitasnya dibawah 128 maka akan diubah menjadi warna hitam (nilai intensitas 0) dan pixel yang nilainya 128 maka akan diubah menjadi warna putih 
e. Deteksi Poin Marker

Proses deteksi poin marker menggunakan metode Features from Accelerated Segment Test (FAST) Corner Detection atau lebih dikenal dengan metode FCD. Metode FCD digunakan untuk menentukan titik objek dan pencocokan pola pada marker. Output dari metode FCD adalah penentuan jumlah titik atau poin pada marker. Proses perhitungan algoritma ini dimulai dari penentuan titik p pada koordinat yang didefinisikan oleh koordinat (xp, yp). Tahap proses algoritma FCD sebagai berikut :

1. Tentukan sebuah titik $p$ pada citra dengan posisi awal $(\mathrm{x}, \mathrm{y})$ dan nilai threshold seperti pada Gambar 19.
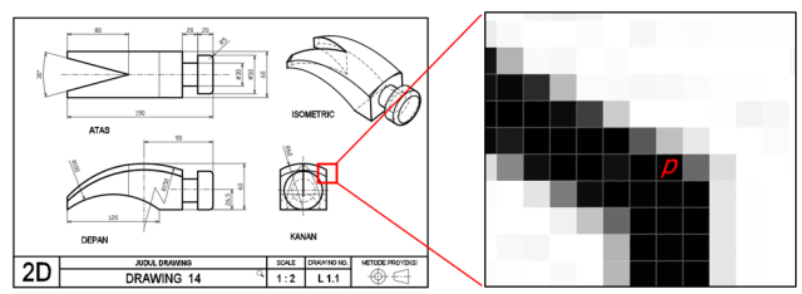

Gambar 19. Menentukan titik awal (titik P)

2. Tentukan 16 titik pixel dengan radius 3 pixel dari titik $p$ seperti pada Gambar 20.
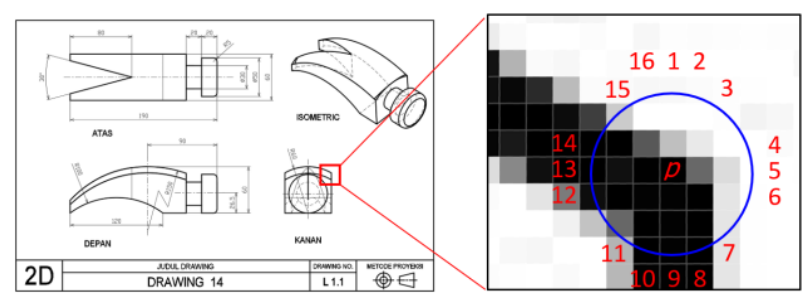

Gambar 20. Menentukan titik awal (titik P)

3. Tentukan empat titik dari 16 pixel. Titik pertama $(\mathrm{n}=1)$ koordinat $\left(x_{p}, y_{p+3}\right)$, titik kedua $(\mathrm{n}=2)$ koordinat $\left(x_{p+3}, y_{p}\right)$, titik ketiga $(\mathrm{n}=3)$ koordinat $\left(x_{p}, y_{p-3}\right)$, titik keempat $(\mathrm{n}=2)$ koordinat $\left(x_{p-3}, y_{p}\right)$ seperti pada Gambar 21.
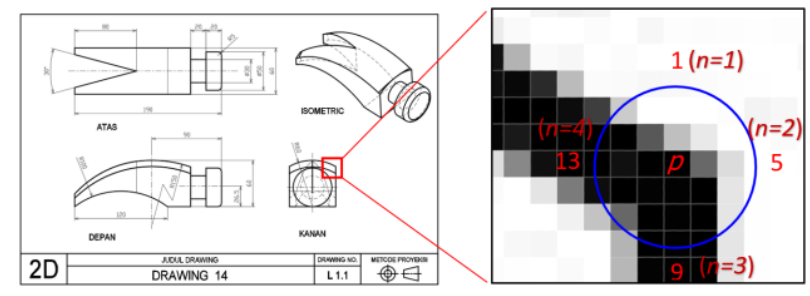

Gambar 21. Titik p pada koordinat $n=1, n=2, n=3, n=4$

4. Bandingkan intensitas titik pusat $p$ dengan keempat titik disekitar. Jika terdapat paling sedikit 3 titik yang memenuhi syarat, maka titik pusat $p$ merupakan titik sudut seperti pada Gambar 22.

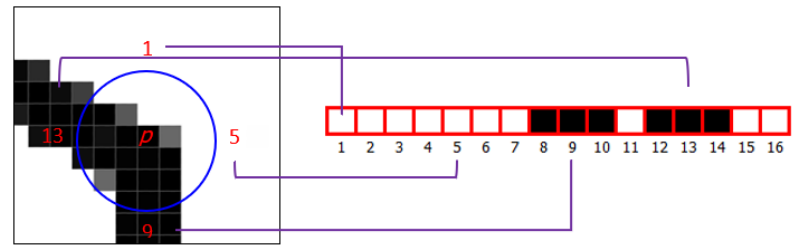

Gambar 22. Perbandingan intensitas pada 16 pixel dari titik $\mathrm{p}$
5. Ulangi proses sampai seluruh titik pada citra sudah dibandingkan intensitasnya.

Hasil dari proses deteksi poin marker dapat dilihat pada Gambar 23.

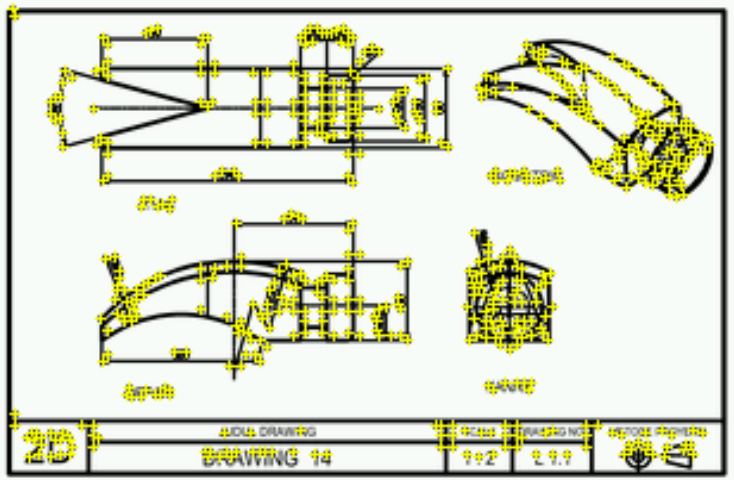

Gambar 23. Hasil proses deteksi poin metode FCD

\section{Visualisasi Objek 3D Virtual}

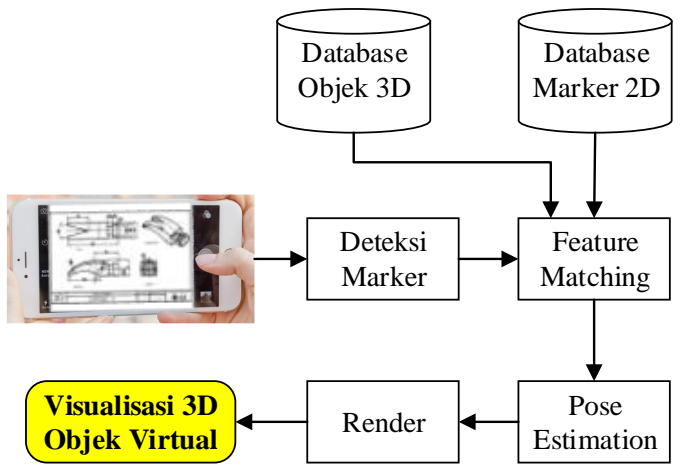

Gambar 24. Tahapan Visualisasi Objek 3D

Visualisasi objek 3D pada aplikasi dilakukan dengan terlebih dahulu mendeteksi drawing 2D atau marker. Kemudian melakukan proses matching antara marker yang telah di proses tracking dengan drawing 2D pada dunia nyata. Jika hasilnya sama maka dilakukan input objek 3D virtual dan proses render. Tahapan visualisasi seperti pada Gambar 24. Ilustrasi visualisasi aplikasi seperti pada Gambar 25.

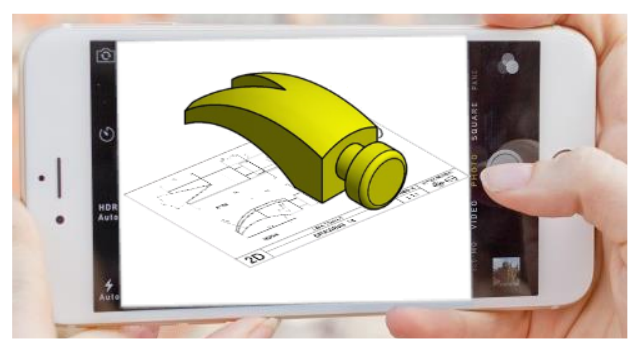

Gambar 25. Ilustrasi render objek pada unity

\section{User Interface}

Aplikasi Augmented Reality pembelajaran drawing 2D yang akan diujikan dibuat menggunakan editor unity seperti pada Gambar 26.

Aplikasi terdapat menu button utama yaitu button pandangan/view objek yang dapat menampilkan jenis pandangan depan, belakang, samping kiri, samping kanan, 
atas dan bawah. Button auto rotasi dapat memutar objek 3D secara continue terhadap sumbu X, Y dan Z. Untuk menu Zoom in dan out atau skala objek serta rotasi objek secara manual dapat menggunakan jari.

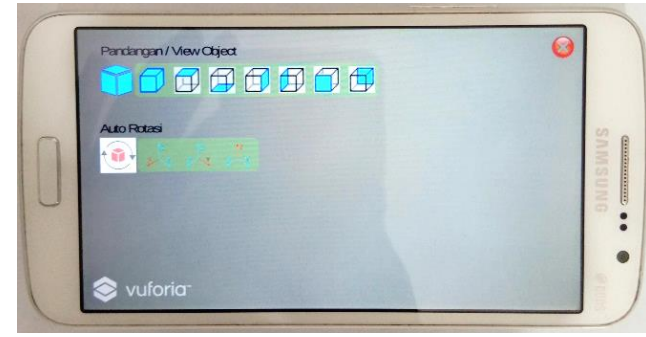

Gambar 26. User interface aplikasi AR drawing 2D

\section{UJI COBA DAN HASIL}

\section{A. Kriteria Pengujian}

Uji coba aplikasi augmented reality menggunakan perangkat smartphone dengan spesifikasi seperti pada Tabel 3.

Tabel 3

Spesifikasi perangkat uji coba aplikasi AR

\begin{tabular}{ccccc}
\hline \hline Perangkat & OS & CPU & Resolusi & Kamera \\
\hline Samsung & Android & Quad-core 1.2 & $720 \times 1280$ & $2 \mathrm{MP}$ dan \\
Grand 2 & 4.42 & $\mathrm{GHz}$ & pixels & $8 \mathrm{MP}$ \\
& Android & Snapdragon & $720 \times 1280$ & $5 \mathrm{MP}$ dan \\
Vivo Y35 & 5.02 & 410 Quad-core & pixels & $13 \mathrm{MP}$ \\
& & $1.2 \mathrm{GHz}$ & \\
\hline \hline
\end{tabular}

Kriteria untuk uji coba deteksi marker atau drawing 2D sebagai berikut :

1. Maksimum deteksi marker : 1 detik

2. Ukuran marker : $18 \times 11 \mathrm{~cm}$.

3. Jumlah marker uji coba : 50 drawing $2 \mathrm{D}$.

4. Tempat uji coba dengan ruangan $3 \mathrm{~m} \times 3 \mathrm{~m}$.

5. Penerangan menggunakan lampu philip 20 watt.

6. Jarak deteksi marker dengan kamera : $20 \mathrm{~cm}, 30 \mathrm{~cm}, 40$ $\mathrm{cm}, 50 \mathrm{~cm}, 60 \mathrm{~cm}$

7. Posisi marker terhadap kamera :

- Marker tegak lurus terhadap kamera.

- Marker dimiringkan $30^{\circ}, 45^{\circ}, 60^{\circ}$ dan $75^{\circ}$ terhadap kamera.

Visualisasi untuk pengujian deteksi marker seperti pada Gambar 27, Gambar 28 dan Gambar 29.

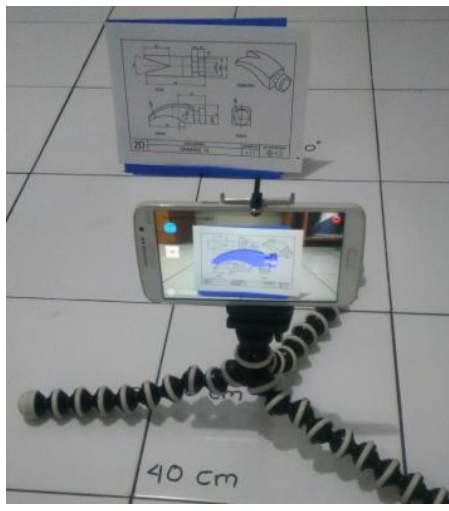

Gambar 27. Visualisasi cara deteksi marker

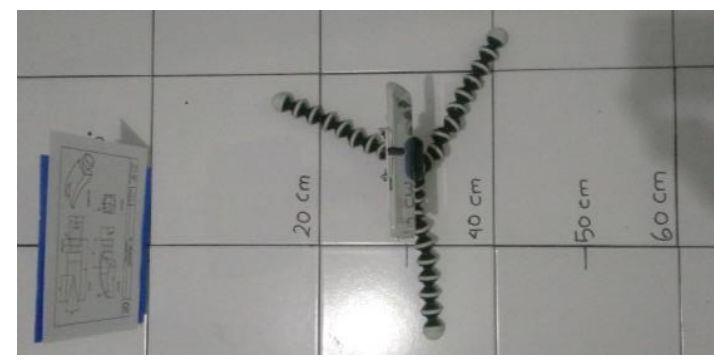

Gambar 28. Cara uji coba deteksi dengan marker tegak lurus terhadap kamera

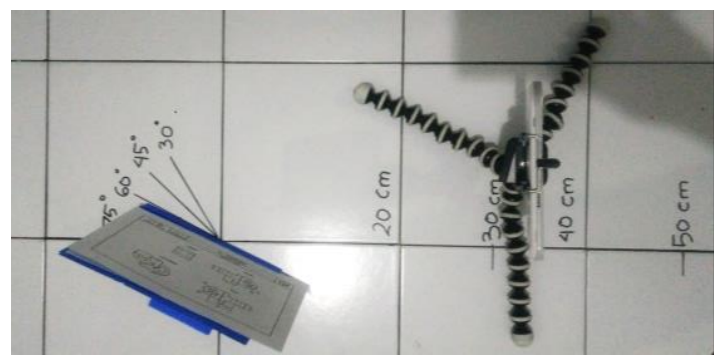

Gambar 29. Cara uji coba deteksi dengan marker dimiringkan $30^{\circ}, 45^{\circ}, 60^{\circ}$, dan $75^{\circ}$ terhadap kamera

\section{B. Hasil uji coba}

1. Uji Coba Deteksi Marker

Hasil dari uji coba deteksi marker dengan lama waktu deteksi maksimum 1 detik sebagai berikut :

Tabel 4

Uji coba deteksi dengan marker tegak lurus terhadap kamera

\begin{tabular}{ccccc}
\hline \hline \multirow{2}{*}{$\begin{array}{c}\text { Jarak } \\
\text { Deteksi }\end{array}$} & \multicolumn{2}{c}{$\begin{array}{c}\text { Jumlah Marker Terdeteksi } \\
(\text { Pcs })\end{array}$} & $\begin{array}{c}\text { Jumlah Marker Tidak } \\
\text { Terdeteksi (Pcs) }\end{array}$ \\
\cline { 2 - 5 } & $\begin{array}{c}\text { Samsung } \\
\text { Grand 2 }\end{array}$ & Vivo Y35 & $\begin{array}{c}\text { Samsung } \\
\text { Grand 2 }\end{array}$ & Vivo Y35 \\
\hline 20 & 50 & 50 & - & - \\
30 & 50 & 50 & - & - \\
40 & 50 & 50 & - & - \\
50 & 38 & 50 & 12 & - \\
60 & - & 50 & 50 & - \\
\hline \hline
\end{tabular}

Untuk tambahan hasil pengujian dengan dengan marker tegak lurus terhadap kamera pada Tabel 4 sebagai berikut :

- Perangkat Vivo Y35

Pada jarak $70 \mathrm{~cm}$ masih dapat mendeteksi marker dengan waktu 2-3 detik. Sedangkan pada jarak $80 \mathrm{~cm}$ sudah tidak dapat mendeteksi marker.

Tabel 5

Uji coba deteksi dengan marker miring $30^{\circ}$ terhadap kamera

\begin{tabular}{ccccc}
\hline \hline \multirow{2}{*}{$\begin{array}{c}\text { Jarak } \\
\text { Deteksi } \\
(\mathrm{Cm})\end{array}$} & $\begin{array}{c}\text { Jumlah Marker Terdeteksi } \\
(\text { Pcs })\end{array}$ & $\begin{array}{c}\text { Jumlah Marker Tidak } \\
\text { Terdeteksi (Pcs) }\end{array}$ \\
\cline { 2 - 5 } & $\begin{array}{c}\text { Samsung } \\
\text { Grand 2 }\end{array}$ & Vivo Y35 & $\begin{array}{c}\text { Samsung } \\
\text { Grand 2 }\end{array}$ & Vivo Y35 \\
\hline 20 & 50 & 50 & - & - \\
30 & 50 & 50 & - & - \\
40 & 50 & 50 & - & - \\
50 & - & 31 & 50 & 19 \\
60 & - & 29 & 50 & 21 \\
\hline \hline
\end{tabular}


Untuk tambahan hasil pengujian dengan kemiringan marker $30^{\circ}$ pada Tabel 5 sebagai berikut :

- Perangkat Samsung Grand 2

Pada jarak $50 \mathrm{~cm}$ masih dapat mendeteksi 17 marker dengan waktu 2-3 detik, 33 marker lainnya tidak dapat terdeteksi.

Untuk jarak $60 \mathrm{~cm}$ sudah tidak dapat mendeteksi marker.

- Perangkat Vivo Y35

Pada jarak $50 \mathrm{~cm}$ masih dapat mendeteksi 14 marker dengan waktu 2-3 detik, 5 marker lainnya tidak dapat terdeteksi.

Pada jarak $60 \mathrm{~cm}$ masih dapat mendeteksi 12 marker dengan waktu 3-6 detik, 9 marker lainnya tidak dapat terdeteksi.

Tabel 6

Uji coba deteksi dengan marker miring $45^{\circ}$ terhadap kamera

\begin{tabular}{ccccc}
\hline \hline \multirow{2}{*}{$\begin{array}{c}\text { Jarak } \\
\text { Deteksi } \\
(\text { Cm) }\end{array}$} & \multicolumn{2}{c}{$\begin{array}{c}\text { Jumlah Marker Terdeteksi } \\
\text { (Pcs) }\end{array}$} & $\begin{array}{c}\text { Jumlah Marker Tidak } \\
\text { Terdeteksi (Pcs) }\end{array}$ \\
\cline { 2 - 5 } & $\begin{array}{c}\text { Samsung } \\
\text { Grand 2 }\end{array}$ & Vivo Y35 & $\begin{array}{c}\text { Samsung } \\
\text { Grand 2 }\end{array}$ & Vivo Y35 \\
\hline 20 & 28 & 50 & 22 & - \\
30 & 50 & 50 & - & - \\
40 & - & - & 50 & 50 \\
50 & - & - & 50 & 50 \\
60 & - & - & 50 & 50 \\
\hline \hline
\end{tabular}

Untuk tambahan hasil pengujian dengan kemiringan marker $45^{\circ}$ pada Tabel 6 sebagai berikut :

- Perangkat Samsung Grand 2

Pada jarak $20 \mathrm{~cm}$ masih dapat mendeteksi 8 marker dengan waktu 3-6 detik, 14 marker lainnya tidak dapat terdeteksi

Pada jarak $40 \mathrm{~cm}$ masih dapat mendeteksi 18 marker dengan waktu 3-6 detik, 32 marker lainnya tidak dapat terdeteksi

- Perangkat Vivo Y35

Pada jarak $40 \mathrm{~cm}$ masih dapat mendeteksi 20 marker dengan waktu 3-6 detik, 30 marker lainnya tidak dapat terdeteksi.

Tabel 7

Uji coba deteksi dengan marker miring $60^{\circ}$ terhadap kamera

\begin{tabular}{|c|c|c|c|c|}
\hline \multirow{2}{*}{$\begin{array}{c}\text { Jarak } \\
\text { Deteksi } \\
(\mathrm{Cm})\end{array}$} & \multicolumn{2}{|c|}{$\begin{array}{c}\text { Jumlah Marker Terdeteksi } \\
\text { (Pcs) }\end{array}$} & \multicolumn{2}{|c|}{$\begin{array}{l}\text { Jumlah Marker Tidak } \\
\text { Terdeteksi (Pcs) }\end{array}$} \\
\hline & $\begin{array}{l}\text { Samsung } \\
\text { Grand } 2 \\
\end{array}$ & Vivo Y35 & $\begin{array}{l}\text { Samsung } \\
\text { Grand } 2 \\
\end{array}$ & Vivo Y35 \\
\hline 20 & - & 16 & 50 & 34 \\
\hline 30 & - & - & 50 & 50 \\
\hline 40 & - & - & 50 & 50 \\
\hline 50 & - & - & 50 & 50 \\
\hline 60 & - & - & 50 & 50 \\
\hline
\end{tabular}

Untuk tambahan hasil pengujian dengan kemiringan marker $60^{\circ}$ pada Tabel 7 sebagai berikut :

- Perangkat Vivo Y35

Pada jarak $20 \mathrm{~cm}$ dapat mendeteksi 21 marker dengan waktu 2-4 detik, 13 marker lainnya tidak dapat terdeteksi.
Tabel 8

Uji coba deteksi dengan marker miring $75^{\circ}$ terhadap kamera

\begin{tabular}{ccccc}
\hline \hline \multirow{2}{*}{$\begin{array}{c}\text { Jarak } \\
\text { Deteksi } \\
(\mathrm{Cm})\end{array}$} & $\begin{array}{c}\text { Jumlah Marker Terdeteksi } \\
(\text { Pcs })\end{array}$ & \multicolumn{2}{c}{$\begin{array}{c}\text { Jumlah Marker Tidak } \\
\text { Terdeteksi (Pcs) }\end{array}$} \\
\cline { 2 - 5 } & $\begin{array}{c}\text { Samsung } \\
\text { Grand 2 }\end{array}$ & Vivo Y35 & $\begin{array}{c}\text { Samsung } \\
\text { Grand 2 }\end{array}$ & Vivo Y35 \\
\hline 20 & - & 9 & 50 & 41 \\
30 & - & - & 50 & 50 \\
40 & - & - & 50 & 50 \\
50 & - & - & 50 & 50 \\
60 & - & - & 50 & 50 \\
\hline \hline
\end{tabular}

Tambahan hasil pengujian dengan kemiringan marker $75^{\circ}$ pada Tabel 8 untuk perangkat Vivo Y35 berhasil mendeteksi 9 marker dengan kriteria drawing 2D yang komplesk sehingga hasil deteksi poin lebih banyak daripada gambar yang sederhana.

\section{Uji Coba Tool Pada User Interface}

Tool pada user interface terdiri dari button view atau pandangan dan button auto rotasi. Untuk button pandangan/view objek dapat menunjukkan jenis pandangan objek yang terdiri dari pandangan isometrik, pandangan atas, pandangan bawah, pandangan samping kiri, pandangan samping kanan, pandangan depan dan pandangan belakang. Sedangkan untuk button auto rotasi dapat merotasi objek terhadap sumbu X, sumbu Y dan sumbu Z.

Untuk proses zoom in dan zoom out objek dapat menggunakan interaksi dua jari. Sedangkan untuk proses rotasi objek secara manual dapat menggunakan satu jari.

Hasil ujicoba untuk jenis pandangan objek dengan proyeksi amerika terdapat pada Tabel 9.

Tabel 9

Hasil ujicoba jenis pandangan objek proyeksi amerika

\begin{tabular}{ccc}
\hline \hline Judul & Jenis & \\
Drawing & Proyeksi & Pandangan Objek 3D \\
& Amerika & \\
\hline
\end{tabular}

Drawing $14 \quad$ Pandangan

Isometrik

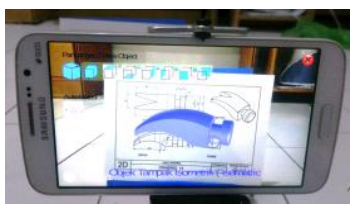

$\begin{array}{cc}\text { Drawing 14 } & \begin{array}{c}\text { Pandangan } \\ \text { Atas }\end{array} \\ \text { Drawing 14 } & \begin{array}{c}\text { Pandangan } \\ \text { Bawah }\end{array}\end{array}$
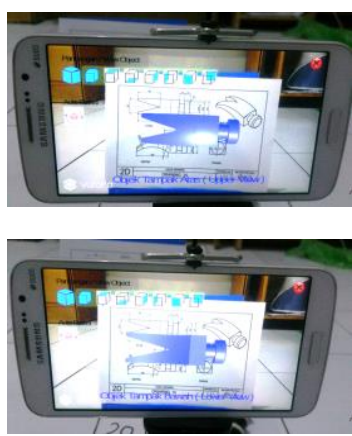

Samping

Kanan

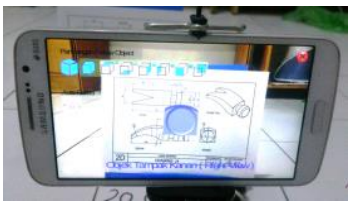




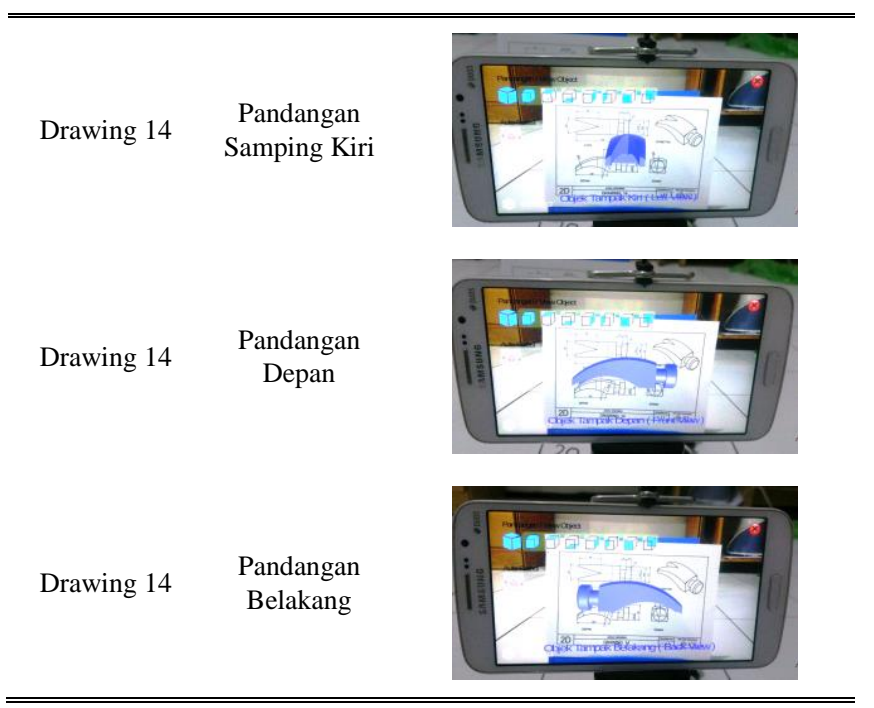

Hasil ujicoba untuk rotasi objek terhadap sumbu X, sumbu $\mathrm{Y}$ dan sumbu $\mathrm{Z}$ terdapat pada Tabel 10.

Tabel 10

Hasil ujicoba rotasi pada sumbu $\mathrm{X}, \mathrm{Y}$ dan $\mathrm{Z}$

\begin{tabular}{|c|c|c|}
\hline $\begin{array}{c}\text { Judul } \\
\text { Drawing }\end{array}$ & $\begin{array}{c}\text { Jenis Rotasi } \\
\text { Objek }\end{array}$ & Pandangan Objek 3D \\
\hline Drawing 2 & $\begin{array}{c}\text { Rotasi objek } \\
\text { sumbu X }\end{array}$ & \\
\hline Drawing 2 & $\begin{array}{c}\text { Rotasi objek } \\
\text { sumbu Y }\end{array}$ & \\
\hline Drawing 2 & $\begin{array}{c}\text { Rotasi objek } \\
\text { sumbu Z }\end{array}$ & \\
\hline
\end{tabular}

Sedangkan hasil ujicoba untuk interaksi objek menggunakan jari pada Tabel 11.

Tabel 11

Hasil ujicoba interaksi menggunakan jari

\begin{tabular}{ccc}
\hline Judul & $\begin{array}{c}\text { Jenis } \\
\text { Interaksi } \\
\text { pada Aplikasi }\end{array}$ & Pandangan Objek 3D \\
\hline Drawing 2 & $\begin{array}{c}\text { Zoom In dan } \\
\text { Zoom Out }\end{array}$ \\
Drawing 2 & $\begin{array}{c}\text { Rotasi objek } \\
\text { manual }\end{array}$ \\
\hline \hline
\end{tabular}

\section{KESIMPULAN}

Pada penelitian yang dilakukan, telah dikembangkan aplikasi Augmented Reality untuk memvisualisasikan drawing 2D ke dalam bentuk objek 3D dengan marker based tracking menggunakan algoritma Features from Accelerated Segment Test (FAST) Corner Detection.

Resume dari hasil deteksi marker menggunakan perangkat Samsung Grand 2 dapat dilihat pada Tabel 12 dan Gambar 30.

Tabel 12. Resume marker terdeteksi dengan perangkat Samsung Grand 2

\begin{tabular}{cccccc}
\hline \hline \multirow{2}{*}{$\begin{array}{c}\text { Jarak } \\
(\mathrm{Cm})\end{array}$} & \multicolumn{5}{c}{ Jumlah Marker Terdeteksi dengan Posisi Marker Terhadap } \\
\cline { 2 - 6 } & Tegak & Miring & Miring & Miring & Miring \\
& Lurus & $30^{\circ}$ & $45^{\circ}$ & $60^{\circ}$ & $75^{\circ}$ \\
\hline 20 & 50 & 50 & 28 & - & - \\
30 & 50 & 50 & 50 & - & - \\
40 & 50 & 50 & - & - & - \\
50 & 38 & - & - & - & - \\
60 & - & - & - & - & - \\
\hline \hline
\end{tabular}

\section{Jumlah Marker Terdeteksi dengan Perangkat Samsung Grand 2}

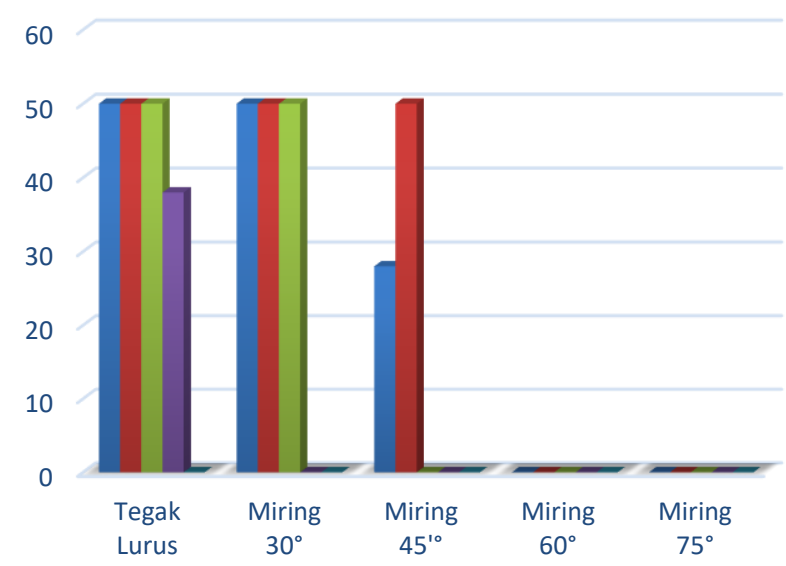

- Jarak $20 \mathrm{~cm}$ Jarak $30 \mathrm{~cm}$ Jarak $40 \mathrm{~cm}$ Jarak $50 \mathrm{~cm}$ Jarak $60 \mathrm{~cm}$

Gambar 30. Jumlah Marker Terdeteksi Pada Perangkat Samsung Grand 2

Resume dari hasil deteksi marker menggunakan perangkat Vivo Y35 dapat dilihat pada Tabel 13 dan Gambar 31.

Tabel 13

Resume marker terdeteksi dengan perangkat Vivo Y35

\begin{tabular}{cccccc}
\hline \hline \multirow{5}{*}{$\begin{array}{c}\text { Jarak } \\
(\mathrm{Cm})\end{array}$} & \multicolumn{5}{c}{ Jumlah Marker Terdeteksi dengan Posisi Marker Terhadap } \\
\cline { 2 - 6 } & $\begin{array}{c}\text { Tegak } \\
\text { Kurus }\end{array}$ & $\begin{array}{c}\text { Miring } \\
30^{\circ}\end{array}$ & $\begin{array}{c}\text { Miring } \\
45^{\circ}\end{array}$ & $\begin{array}{c}\text { Miring } \\
60^{\circ}\end{array}$ & $\begin{array}{c}\text { Miring } \\
75^{\circ}\end{array}$ \\
\hline 20 & 50 & 50 & 50 & 16 & 9 \\
30 & 50 & 50 & 50 & - & - \\
40 & 50 & 50 & - & - & - \\
50 & 50 & 31 & - & - & - \\
60 & 50 & 29 & - & - & - \\
\hline \hline
\end{tabular}




\section{Jumlah Marker Terdeteksi dengan Perangkat} Vivo Y35

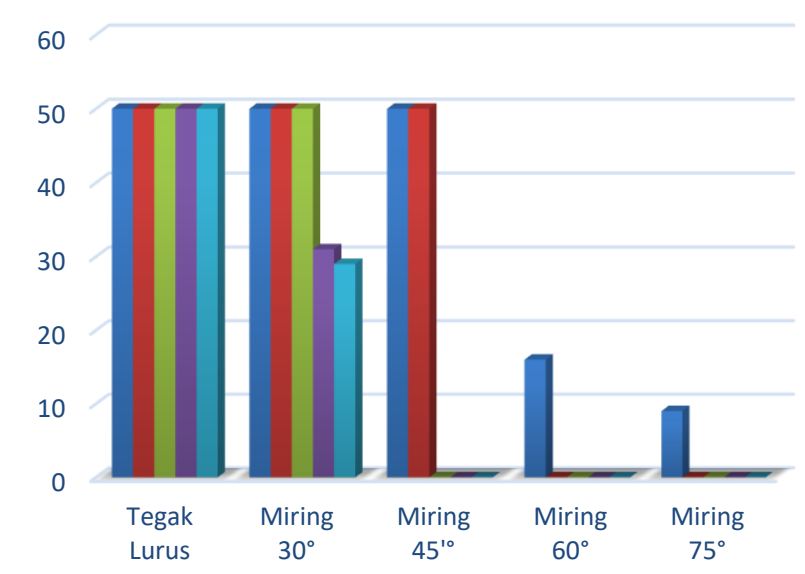

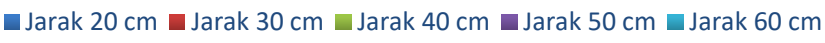

Gambar 31. Jumlah Marker Terdeteksi Pada Perangkat Vivo Y35

Dari Gambar 30 dan Gambar 31 disimpulkan bahwa rata-rata marker dapat terdeteksi dengan posisi marker tegak lurus terhadap kamera maksimum pada jarak $50 \mathrm{~cm}$. Sedangkan untuk posisi marker dimiringkan $30^{\circ}$ terhadap kamera marker dapat terdeteksi rata-rata pada jarak maksimum $40 \mathrm{~cm}$. Uji coba posisi marker dimiringkan $45^{\circ}$ terhadap kamera marker dapat terdeteksi rata-rata pada jarak maksimum $30 \mathrm{~cm}$. Untuk posisi marker dengan kemiringan $60^{\circ}$ dan $75^{\circ}$ terhadap kamera rata-rata perangkat tidak dapat mendeteksi marker.

Untuk user interface, tool yang digunakan untuk membantu proses belajar dapat berjalan sesuai dengan perintah. Proses deteksi marker dapat dipengaruhi oleh spesifikasi perangkat untuk melakukan pengujian. Semakin tinggi spesifikasi perangkat terutama besarnya pixel kamera mempengaruhi tingkat kecepatan dalam proses deteksi marker. Kemudian pencahayaan lampu dapat berpengaruh terhadap auto fokus kamera. Semakin gelap pencahayaan maka semakin lama proses deteksi marker. Selain itu besar kecilnya ukuran marker serta ketebalan garis yang digunakan juga mempengaruhi proses deteksi. Semakin kecil marker dan garis yang tipis maka semakin sulit untuk melacak poin marker dan auto fokus dari kamera.

\section{DAFTAR PUSTAKA}

[1] R. T. Azuma, "A Survey of Augmented Reality," vol. 4, pp. 355385, 1997.

[2] Y. Gao, H. Wang, and X. Bian, "MARKER TRACKING FOR VIDEO-BASED AUGMENTED REALITY,” pp. 10-13, 2016.

[3] T. Kan, C. Teng, and M. Y. Chen, "QR Code Based Augmented Reality Applications," 2011.

[4] G. Kipper, Augmented Reality An Emerging Technologies Guide to $A R$. Elsevier, 2013.

[5] G. T. Sato and N. S. Hartanto, Menggambar mesin menurut standard ISO. 1986.

[6] J. Martín-gutiérrez, M. Contero, and M. Alcañiz, "Augmented Reality to Training Spatial Skills," Procedia - Procedia Comput. Sci., vol. 77, pp. 33-39, 2015.

[7] H. Chen, K. Feng, C. Mo, S. Cheng, Z. Guo, and Y. Huang, "Application of Augmented Reality in Engineering Graphics
Education."

[8] E. R. S. Siswanto, "PERBANDINGAN METODE HARRIS CORNER DETECTION , EDGE BASED CORNER DETECTION DAN FAST CORNER DETECTION DALAM APLIKASI PENDETEKSI SENYUM PADA WAJAH MANUSIA Oleh Eduard Royce Siswanto NIM : 612009003 Skripsi Untuk melengkapi syaratsyarat memperoleh Ijasah Sar," 2013.

[9] P. Milgram, "Mixed Reality ( MR ) Reality-Virtuality ( RV ) Continuum," vol. 2351, pp. 282-292, 1994.

[10] H. Kato, K. Tachibana, M. Tanabe, T. Nakajima, and Y. Fukuda, "MagicCup : A Tangible Interface for Virtual Objects Manipulation in Table-Top Augmented Reality," pp. 4-5.

[11] E. Rosten and T. Drummond, "Machine learning for high-speed corner detection," pp. 1-14.

[12] E. Rosten and T. Drummond, "Fusing Points and Lines for High Performance Tracking."

[13] J. Mart1, M. Ortega, and D. C. Pe, "Design and validation of an augmented book for spatial abilities development in engineering students," vol. 34, pp. 77-91, 2010.

[14] R. E. Saputro, "Perbandingan Kinerja Algoritma Untuk Mendeteksi Objek Dua Dimensi Pada Augmented Reality," vol. 6, no. 2, pp. $57-$ 74, 2013.

Nanang Wahyudi lahir di Sidoarjo, Jawa Timur, Indonesia, pada tahun 1987. Dia menyelesaikan studi S1 di program studi Teknik Informatika Universitas Muhammadiyah Sidoarjo pada tahun 2011, dan menyelesaikan studi masternya pada jurusan Teknologi Informasi di STTS Surabaya. Minat penelitiannya adalah bidang Artificial Intelligence.

Reddy Alexandro Harianto lahir di Surabaya, Jawa Timur, Indonesia, pada tahun 1989. Dia menyelesaikan studi S1 di program studi Teknik Informatika Sekolah Tinggi Teknik Surabaya pada tahun 2011, dan menyelesaikan studi masternya pada jurusan Teknologi Informatika di Institut Teknologi Sepuluh Nopember Surabaya pada tahun 2015. Minat penelitiannya adalah bidang Artificial Intelligence, Computer Vision, Data Mining. 